\title{
Framing "S" in the BRICs of Brazil, Russia, India and China with Poverty and Inequality: the Goldman Sachs Conception versus Practice
}

\author{
Professor Johannes Tsheola \\ Department of Development Planning \& Management, \\ University of Limpopo, South Africa \\ johannes.tsheola@ul.ac.za
}

\section{Doi:10.5901/mjss.2014.v5n20p771}

\section{Abstract}

In 2001 the Goldman Sachs conceived a set of emerging markets of Brazil, Russia, India and China as the future engine of global growth. The global financial crisis in the later years of the twenty-first century heightened the significance of several sets of emerging markets as future global business, financial and investment hubs. Inspired by such conceptions, sets of emerging markets such as the BRICs, the Next-11 and the self-described G5 of "big emerging states" of China, India, Brazil, South Africa and Mexico, characterised as B(R)ICSAM, emerged. Based on the original Goldman Sachs conception, the BRICs of Brazil, Russia, India and China was established in 2009 and the acronym became famous, virtually cajoling South Africa to fervently seek and cede membership thereof in 2011. This article argues that South Africa's twenty years of economic freedom policies, attendant to enduring poverty and inequality, do not justify the framing of the "S" in the BRICs of Brazil, Russia, India and China. Goldman Sachs' original conception of the BRICs, which excluded South Africa, forecasts that the set would become the future engine of global growth with the proviso that four core conditions of macro-stability, "good" institutions, openness and education, necessary for rapid growth and attractiveness to foreign investment, are established. This article aims to demonstrate that the framing of "S" in the BRICs to include South Africa, given the founding conceptual rationale for the set and the twenty years of this country's economic freedom policies, enduring poverty and inequality, means that membership of the set is not a panacea for national development challenges. The article concludes that South Africa's self-selection of the BRICS membership entails exposure to external vulnerability because the set espouses the economic freedom and openness policies that have been associated with enduring poverty and stark inequality in this country.

Keywords: Emerging Markets; Goldman Sachs; BRICs; Framing "S"; Openness Policies; Poverty; Inequality

\section{Introduction}

Goldman Sachs originally conceived the BRICs set of emerging markets of Brazil, Russia, India and China as prospective future engines of growth in 2001; and, the forecast was subsequently revised in 2003, 2005 and 2010. Even in the latter forecasts, Goldman Sachs excluded South Africa from the set because this country did not meet the necessary demographic and economic tenets of the conception. According to de Paula (n.d.), the BRICs economic performance is partially explicable through the quality of the member states' macroeconomic policies, especially those relating to the management of exchange rate, capital account convertibility and the degree of external vulnerability. Given the potential for demographic momentum and capital accumulation, Goldman Sachs posited that these emerging markets offered unique foreign investment opportunities and, therefore, demand elasticity that would serve the developed economies (Wilson and Purushothaman, 2003; O'Neill, Wilson, Purushothaman and Stupnytska, 2005; Cheng, Gutierrez, Mahajan, Shachmurove and Shahrokhi, 2007; Wilson, Kelston and Ahmed, 2010). Understandably, the original BRICs framing in 2001 and establishment in 2009 excluded South Africa, which subsequently sought to use the IBSA (India, Brazil and South Africa) to secure membership of the BRICs (Calland, 2013; Habib, 2013). Ultimately, it was through its relationship with China that South Africa secured membership of the BRICS (Calland, 2013; Habib, 2013). Given the increasing prominence of China's "Red Capitalism" on the global stage, South Africa's strive to join the BRICs has to be understood in the context of this set becoming globally famous, in comparison with the IBSA, the CIBS (China, India, Brazil and South Africa) and the B(R)ICSAM (Brazil, Russia, India, China, South Africa and Mexico) of the so-called self-described G5 of "big emerging states" (Armijo and Echeverri-Gent, 2006; MacFarlane, 2006; Armijo, 2007; Cheng et al., 2007; Cooper, 2009; Tandon and Shome, 2009; Glosny, 2010; Bell, 2011). Indeed, it is this most illogical and irrational set of the BRICS that came to dominate the global business and financial circles. 
This article aims to demonstrate that the framing of "S" in the BRICs to include South Africa, given the founding conceptual rationale for the set and the twenty years of this country's economic freedom policies, enduring poverty and inequality, means that membership of the set is not a panacea for resolving national development challenges. It argues that South Africa's twenty years of economic freedom policies, attendant to enduring poverty and inequality, do not justify the framing of the "S" in the BRICs of Brazil, Russia, India and China because Goldman Sachs' original conception of the BRICs is predicated upon the proviso that four core conditions of macro-stability, "good" institutions, openness and education, necessary for rapid growth and attractiveness to foreign investment, are established. The article concludes that South Africa's self-selection of the BRICS membership entails exposure to external vulnerability because the set espouses the economic freedom and openness policies that have been associated with enduring poverty and stark inequality in this country. That is, it dismisses the glorification of South Africa's membership of the BRICS as panacea for addressing national development challenges of poverty and inequality. Besides, the cognitive basis for framing the "S" in the BRICS is problematic because South Africa does not have the "miracle conditions" to satisfy the necessary demographic and economic conditions for membership of the BRICs, as prescribed by Goldman Sachs.

\section{Goldman Sachs' Conception of the BRICs: Questionable Framing of "S" in the BRICS}

Goldman Sachs' original business and financial conceptual framing of the BRICs is that the four emerging economies of Brazil, Russia, India and China are "large" in sheer demographic and economic size that they consist of productivity and demand elasticity potential necessary for economic dynamism that would attract foreign direct investment (Wilson and Purushothaman, 2003; O'Neill et al., 2005; Cheng et al., 2007; Wilson et al., 2010). The 2001 Goldman Sachs conception of the BRICs forecasts that these economies would become engines of global growth by 2050, with the proviso that individual countries meet four conditions, which are: macro-stability, especially price stability, development of good institutions, including legal systems, functioning markets, educational systems, financial institutions and so on, openness to trade and foreign direct investment (FDI), and improvement in the education of the population (de Paula, n.d.; Wilson and Purushothaman, 2003; O'Neill et al., 2005; Cheng et al., 2007; Glosny, 2010; Bell, 2011; Wilson et al., 2010). These conditions are commonly described as conventional "Washington Consensus" growth-focused development paradigm, policies and strategies (de Paula, n.d.; Glosny, 2010; Bell, 2011). That is, "the capacity of the BRICs to influence global dynamics turns on their ability to set and maintain growth-supportive policy settings" (O'Neill et al., 2005, p.3), revealing therefore the economic neoliberalism foundational framing of the set. For the four BRICs economies of Brazil, Russia, India and China to realize the forecast growth levels and to be attractive to foreign investors, they are advised to deepen the economic freedom policies (de Paula, n.d.; O'Neil et al., 2005; Cheng et al., 2007; Tandon and Shome, 2009; Glosny, 2010; Wilson et al., 2010; Bell, 2011). At the core of these policies is openness to trade and FDI (MacFarlane, 2006; Bell, 2011), yet O'Neill, the economists who coined the acronym, paradoxically expressed fear of the dangers attendant to globalization (Tandon and Shome, 2009).

However, Goldman Sachs holds that the BRICs set has the potential for exceptionally high future import demand and economic growth (de Paula, n.d.; Armijo and Echeverri-Gent, 2006; MacFarlane, 2006; Armijo, 2007; Cheng et al., 2007; Glosny, 2010; Cameron, 2011) because foreign investors would discern investment opportunities for profit under such circumstances. Indeed, the BRICs set caught the imagination of investors largely because the populous member states were expected to be the "engine of new demand of growth and spending power" (Wilson and Purushothaman, 2003, p.2; Armijo, 2007, p.8; Bell, 2011, p.22). To achieve the predicted growth, the BRICs economies are urged to avoid protectionism and to deepen their openness (O'Neill et al., 2005; Cheng et al., 2007; Glosny, 2010; Wilson et al., 2010; Bell, 2011). Ironically, China outperformed the rest of the BRICs in global competiveness, innovation and sophistication notwithstanding its restrictive controls on capital flows, exchange rate and macroeconomic policies (MacFarlane, 2006; Glosny, 2010). Also, three of the four BRICs member states, China, India and Russia, have managed their exchange rate regimes and macroeconomic policies with restrictive capital account convertibility to create stable environment for economic growth (MacFarlane, 2006; Glosny, 2010; Cameron, 2011). Brazil, on its part, relied on "chaotic liberal and orthodox economic policy of minimal interventionism in exchange rate policy and open current account which led to volatile exchange and interest rates as well as poor economic performance" (de Paula, n.d., p.18). In practice, economic liberalism involves non-discriminatory openness, free trade and investment across borders, which is thought to create conditions necessary for rapid economic growth. But Goldman Sachs economists, O'Neill et al. (2005) and Wilson et al. (2010), argue that whereas "generally progressing", the BRICs set needs "considerable further policy improvement in each" member state. The forecasts and peddling of the business and financial model of the BRICs were always predicated on the assumption that member states would each deepen their economic freedom and openness policies.

This business and financial conceptual framing of the BRICs has itself been questioned because of its reliance on 
demographic and economic size when classical economics was predicated on the rate of growth. Indeed, Armijo (2007, p.12) affirms that "the central organizing principle for the BRICs category is not growth rate, nor opportunities for investor profit, but rather sheer economic size". Armijo (2007, p.14) contests the logic of economic size because it has never been "a core concept within neoclassical economics"; and, drawing on it for the BRICs business and financial framing should be irrational. In practice, "growth nations have lower returns than value nations" (Bernstein, 2006, n.p.), implying that "high national growth rates do not necessarily result in high returns to private investors" (Armijo, 2007, p.11). Besides, the conceptual economic liberalism logic for the business and financial conception of the BRICs was in stark contrast of the prevailing circumstances of the four member states, the necessity of prudent gradualism and careful management of capital accounts and policies in order to reduce external vulnerability, as well as the value of capital controls for protecting the economy against destabilizing aspects of capital flows and the resolution of policy dilemmas (de Paula, n.d.; MacFarlane, 2006; Glosny, 2010; Cameron, 2011). O'Neill et al. (2005, p.3), Goldman Sachs economists at the coalface of the business and financial conception of the BRICs, too accept that "demographic advantage is not sufficient"; and, the global economy does not provide evidence of larger size trumping faster growth rates, "good property-rights, or other economic or financial ratios of interest to private investors" (Armijo, 2007, p.14). That is, Goldman Sachs concedes that demographic advantage alone or "miracle conditions" are insufficient conditions for any country to become future engine of global growth (O'Neill et al., 2005; Wilson et al., 2010). As profitability cannot be determined solely through sheer population and economic size, the BRICs set will, according to Armijo (2007, p.14), remain "an odd and illogical set". Notwithstanding these and such other doubts of the strength of the BRICs expressed by, among others, Tandon and Shome (2009), O'Neill et al. (2005) and Wilson et al. (2010), have firmly adhered to the conviction that BRICs held stronger capacity to become globally important. But evidence suggest that the BRICs has remained "a forced set" and "a sideshow to the main 'club' competitions" on the global stage (de Paula, n.d.; Armijo and Echeverri-Gent, 2006; Armijo, 2007; Cheng et al., 2007; Cooper, 2009; Tandon and Shome, 2009; Glosny, 2010; Bell, 2011; Cameron, 2011).

To Bernstein (2006, n.p.), the economic neoliberalism conception of the BRICs is based on an unrealistic assumption of the relationship between economic growth and equity returns, because whereas "stock returns lead economic growth", the converse does not hold. With economic freedom and openness policies, "any volatility in commodity prices is likely to impact ... current account" balance, an important indicator of economic health of a country (Tandon and Shome, 2009, pp.274-275). South Africa's economy and production structure are heavily dependent on imported inputs. In this context, the article affirms Goldman Sachs' determination that South Africa does not fit the conceptual framing of the BRICs, especially in respect of the demographic and economic preconditions. O'Neill et al. $(2005$, p.4) indicate that their consideration of South Africa in 2003 showed how unlikely this country could "reach the size of any of the BRICs despite its own potential." Their finding was that "by 2050 South Africa's GDP would be much smaller than the smallest BRIC, making it difficult for the country to become a global economic heavy weight" (O'Neill et al., 2005, p.7). How else did South Africa justify its accession to BRICS in 2011? Contrary to the popularity of the BRICs acronym, the set has been inconsequential on the global stage; and, "the BRICs weakened as the members displayed differential rates of growth in most macro indicators" over the past decade (Tandon and Shome, 2009, p.273). Whereas De Paula (n.d.) shows the value of restrictive controls on exchange rate regimes and management of macroeconomic policies in reducing external vulnerability for emerging economies, Hsing (2011) urges for robust deepening of economic freedom and openness policies for South Africa, as a BRICS economy. Thus, the framing of the BRICs from the economic neoliberalism perspectives should suggest that the set is inherently irrational (de Paula, n.d.; MacFarlane, 2006; Glosny, 2010; Cameron, 2011). South Africa does not meet these criteria of being populous; and, O'Neill et al. (2005, p.7) excluded this country because "without a substantial population, even a successful growth story is unlikely to have a global impact". Goldman Sachs' demographic, productivity growth and capital accumulation projections and modelling to 2050 have consistently excluded South Africa from the potentiality of being a future engine of global growth (O'Neill et al., 2005; Wilson et al., 2010). This article shows that the same economic freedom policies touted as conditional panacea for the set becoming the engine of future global economic growth have been associated with trenchant poverty and stark inequality in South Africa, raising therefore eye brows about this country's ceding of membership to the set. It is not surprising that the increasing popularity of the BRICs has been devoid of pragmatic substance on a global stage.

\section{South Africa in the BRICS with Societal Poverty and Inequality}

Goldman Sachs consistently demonstrated that South Africa did not meet the conditions to be in the BRICs (Wilson and Purushothaman, 2003; O'Neill et al., 2005; Wilson et al., 2010). But as already indicated, Hsing (2011, p.12) urges South Africa's government to pursue the economic freedom and openness policies of "economic growth, fiscal prudence, a higher ratio of the money supply to GDP, a lower real interest rate, depreciation of the rand, and/or a lower inflation rate", 
within the BRICS. Nattrass and Seekings (2001) and Khoza (2002) have shown that these same policies are to blame for South Africa's enduring societal poverty and inequality. The GEAR pro-market policies sought to achieve the same objectives; yet, South Africa's life story of the past twenty years is "an engrossing but perilous mix" of poverty and inequality that "the 'miracle' of 1994" did not erase (Bond, 2001; Marais, 2001; Mbeki, 2009; Biko, 2013; Calland, 2013; Habib, 2013). Severe poverty and stark inequality, as well as increasing societal dependence on social assistance have continued unabated; and, dependence on social welfare, measured through the number of beneficiaries, has in the past decade overshot the number of South Africans holding gainful employment (figure 1).

Such a situation illustrates that the economy has performed poorly and that it lacked the capacity to absorb labour; as a result, the unemployment rate in South Africa has hovered around $25 \%$ over the past twenty years. With the economic freedom and openness policies, a democratic South Africa was gripped by precarious "financial and economic conditions" of poverty of the majority and persistent inequality (see Bond, 2001; Marais, 2001; Khoza, 2002; Mbeki, 2009; Biko, 2013; Calland, 2013; Habib, 2013). South Africa or any other developing country, inclusive of those in the BRICS, would abandon the struggles for "more lasting transformations of the structures of politico-economic inequality, poverty and underdevelopment" (Simon, 1995, p.36) if it prioritized the economic freedom and openness policies above justice and political deliberations. South Africa's twenty years of democracy can, at best, be described as perilousness because as the National Planning Commission (NPC, 2012, p.24) in the Office of the Presidency finds, poverty and inequality have remained the stubborn and enduring national development challenges. Whereas inequality was persistently high, $68.1 \%$ of national income accrued to the richest $20 \%$ when the poorest $10 \%$ received only less than $0.57 \%$ (NPC, 2012). The NPC (2012, p.24) records that "the richest $10 \%$ of the population became significantly richer; however their percentage of total income has reduced" over the period 1994 to 2009.

Figure 1: South Africa's Employment and Social Assistance Dependence, 2001-2011

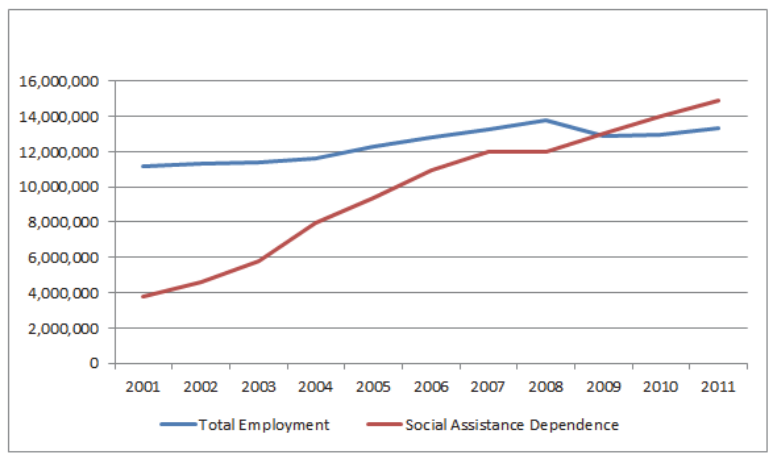

Sources: National Planning Commission (2012); Statistics SA (2012)

Whereas inequality, measured through the gini-coefficient, remained persistently above 0.67 over the past twenty years, the depth and severity of poverty trended between 0.10 and 0.30 during the same period (figure 2). Ceding membership of BRICS, which is urged to pursue the same economic freedom and openness policies that have been associated with the past twenty years of persistent poverty and inequality, would not resolve South Africa's national development challenges. For example, the unemployment rate among the South African youth remained at a high of almost $36 \%$ in 2014 (ANN7 News, June 09, 2014), whereas the narrow official unemployment rate has been about 24\% between 2001 and 2011 (NPC, 2012). During the same period, the economy was unable to accommodate adult able-bodied people because the labour force participation and absorption rate have both declined (NPC, 2012). Simultaneously, the balance on current account, which measures the health of the economy, was negative as a percentage of GDP; and, FDI which the economic freedom and openness policies are presumed to attract was highly unreliable, trending between lows of R44.625 billion (negative) in 2006 to highs of R100.291 billion in 2008 and R9.546 billion in 2010 (NPC, 2012). Following the twenty years of the economic freedom and openness policies, it should not have come as a surprise that South Africa's credit rating was downgraded in 2014 by the Standards and Poors as well as the Moody's, respectively, to BBB and BAA1 with negative outlook (eNCA New, 09 June 2014). To this extent, the decline in poverty rate from $50 \%$ in 1994 to $34.5 \%$ in 2009 is directly linked to the rapid increase in the beneficiaries of state social grants from about 2.5 million to 
15 million between 1993 and 2014, based on the poverty line of R422 per person per month (NPC, 2012; Statistics SA, 2012).

South Africa's marriage to the economic freedom and openness policies over the past twenty years has exposed the country to global gyrations and vulnerability to global commodity prices and the price parity index. The same global neo-libertarian modernity that was reinvented in a democratic South Africa through the 1996 Growth, Employment and Redistribution is now pursued in the 2012 National Development Plan 2030 Vision (Alloggio and Thomas, 2013). According to Alloggio and Thomas (2013), the NDP 2030 Vision is actually placing the burden of resolving the national development challenges of poverty and inequality on the shoulders of the previously disenfranchised by calling for active citizenry without affording appropriate support mechanisms. After twenty years of practice, it has to be conceded that South Africa's economic and production structure do not hold the potentiality to resolve the national development challenges of poverty and inequality through adherence to the economic freedom and openness policies. Membership of the BRICS too would not serve as panacea for redressing South Africa's national development challenges, given that the Goldman Sachs' forecast of these emerging markets becoming the future engine of global growth is predicated on strengthening and deepening openness and neoliberal global modernity. According to Nattrass and Seeking (2001), it is these economic freedom and openness policies that have thwarted a democratic South Africa's capacity to resolve the national development challenges of poverty and inequality. Indeed, the downgrading of South Africa's credit ratings by both the Standards and Poors as well as the Moody's is unambiguous confirmation that this country's economic conditions are, far from those entailed in the Goldman Sachs' conception of the BRICs of Brazil, Russia, India and China, deeply tenuous, precarious and unsustainable. As Nattrass and Seekings (2001) put it, conservative economic models have nowhere in the world ever been amenable to the societal ideals of economic equity and social stability; instead, these policies have served to reproduce poverty and inequality in emerging economies such as South Africa.

Figure 2: Depth and Severity of Poverty, and Gini-coefficient, 1993-2009

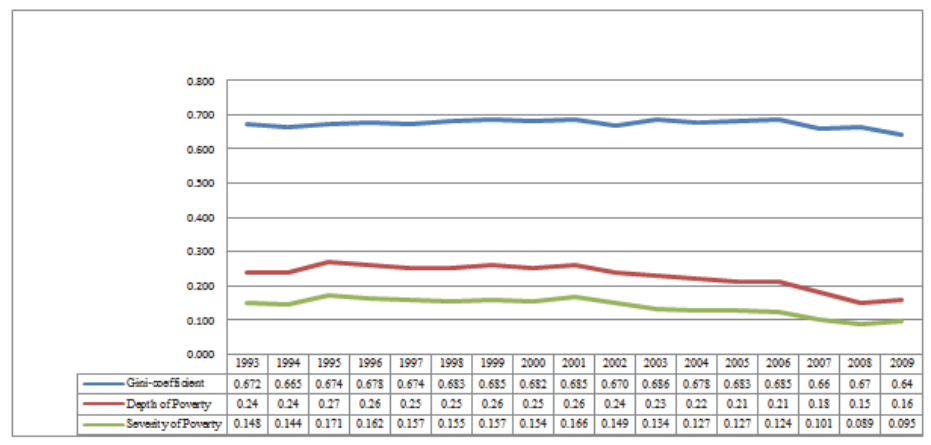

Source: National Planning Commission (2012)

To the extent that the BRICS member states that are evidently authoritarian with direct state control of the economies are relatively equitable, compared to the liberal democracies with substantive economic freedom and openness policies, the conception of the set and the framing of the "S" has to be dismissed as illogical and irrational. In all probability, South Africa's virtually stagnant economy, an increasing proportion of people dependent on state social welfare, especially the $74 \%$ of beneficiaries involving child grant as well as a total number of beneficiaries of social assistance now overshooting the working population, does not auger well for this country's membership of the BRICS, in sharp contrast to the Goldman Sachs forecast that the set would become an engine of global economic growth by 2050. The economic, business and financial preconditions for framing the "S" in the BRICs are non-existent; hence, the Goldman Sachs modelling and forecasting have consistently excluded South Africa from this set. If the set was conceived purely on the demographic and economic sizes, South Africa's population of 49 million and a tenuous domestic economic structure which is highly exposed to external vulnerabilities, heavily import-input dependent, would not meet the criteria for framing the " $S$ " in the BRICs (Cameron, 2011). From an economic perspective alone, the framing of the "S" in the set is illogical because South Africa's current account deficit is extraordinarily large and unique in the BRICS.

\section{Conclusion}


This article has highlighted the cognitive foundations of the Goldman Sachs' conception of the BRICs of Brazil, Russia, India and China; and, has demonstrated that reliance on sheer demographic and economic sizes does not fit the neoclassical business and financial models. Nevertheless, the article has shown that the BRICs acronym became populous, leading to South Africa fiercely seeking for membership through the Chinese diplomacy. It has indicated that South Africa's ultimate ceding of its membership of the BRICS in 2011 was in complete disregard of the consistent exclusion by Goldman Sachs modelling and forecasting in 2001, 2003, 2005 and 2010. The article argued that the framing of the "S" in the BRICS has virtually rendered this grouping a "forced set". Moreover, South Africa's membership of the BRICS implies that this country has to continue to strengthen the same economic freedom and openness policies that have, in the past twenty years, prevented it from resolving the national development challenges of deep poverty and stark inequality. Based on statistical evidence that poverty and inequality in a democratic South Africa have remained enduring whilst economic performance was poor under the neoclassical economic freedom and openness policies, the article concludes that the framing of the "S" for South Africa's membership of the BRICS was an illogical practice that defied Goldman Sachs' measured conception of the set, which has increasingly become striking for its "declaratory than operational force" (Cooper, 2009, n.p). However, the BRICS has simultaneously been enthusiastically repeated and glorified within the foreign investors and international policy fora, far divorced from objective weighing of the merits and demerits of framing the "S" in the set.

\section{References}

Alloggio, S. and Thomas, K. 2013. Resisting the lure of deferral: realising the South African National Development Plan. Social Dynamics: A Journal of African Studies, 39(1), 108-110.

Armijo, L.E. 2007. The BRICs countries (Brazil, Russia, India, and China) as analytical category: mirage or insight? Asian Perspective, $31(4), 7-42$.

Armijo, L.E. and Echeverri-Gent, J. 2006. The politics of global markets: mental models of trade and finance in an unequal world. Public Science Association (APSA) Task Force, Inequality and Difference in the Developing World. APSA, Wahsington, D.C.

Bell, H.A. 2011. Status of the "BRICS": an analysis of growth factors. International Research Journal of Finance \& Economics, 69, $19-25$.

Bernstein, W.J. 2006. Thick as a BRIC. Efficient Frontier Online Journal. http://www.efficientfrontier.com/ef/Oadhoc/bric.htm (Accessed: 12 June 2013).

Biko, H. 2013. The Great African Society: A Plan for a Nation Gone Astray. Jonathan Ball, Johannesburg.

Bond, P. 2001. Against Global Apartheid: South Africa Meets the World Bank, IMF and International Finance. University of Cape Town Press, Cape Town.

Calland, R. 2013. The Zuma Years: South Africa's Changing Face of Power. Zebra Press, Cape Town.

Cameron, F. 2011. The EU and the BRICs. The Jean Monnet Multilateral Research Network on the Diplomatic System of the European Union, Policy Paper 3, February 2011, Loughborough University, UK.

Cheng, H.F., Gutierrez, M., Mahajan, A., Shachmurove, Y. and Shahrokhi, M. 2007. A future global economy to be built by BRICs. Global Finance Journal, 18, 143-156.

Cooper, A.F. 2009. Picking your Club: G8 or G20, BRICs or B(R)ICSAM? Keynote Presentation to Oxfam International on the BRICSAM and the Fight against Global Poverty, July 13, 2009, Geneva.

De Paula, L.F. n.d. Financial liberalization, exchange rate regime and economic performance in BRICs countries. Economia Internacional, 6, 1-20.

Glosny, M.A. 2010. China and the BRICs: a real (but limited) partnership in a unipolar world. Polity, 42(1), 100-129.

Habib, A. 2013. South Africa's Suspended Revolution: Hopes and Prospects. Wits University Press, Johannesburg.

Hall, P.A. and Soskice, D. 2001. Varieties of Capitalism: the Institutional Foundations of Comparative Advantage. Oxford University Press, Oxford.

Hsing, Y. 2011. The stock market and macroeconomic variables in a BRICS country and policy implications. International Journal of Economics and Financial Issues, 1(1), 12-18.

Khosa, M.M. 2002. (Dis)Empowerment through social transformation in South Africa. South African Geographical Journal, 84(1), 21-29.

MacFarlane, S.N. 2006. The "R" in BRICs: is Russia an emerging power? International Affairs, 82(1), 41-57.

Marais, H. 2001. South Africa: Limits to Change, The Political Economy of Transition, $2^{\text {nd }}$ edn. University of Cape Town Press, Cape Town.

Mbeki, M. 2009. Architects of Poverty: Why African Capitalism Needs Changing. Picador Africa, Johannesburg.

National Planning Commission (NPC), 2012. South Africa: Development Indicators. Government Printers, Pretoria.

Nattrass, N. and Seekings, J. 2001. "Two nations?" Race and economic inequality in South Africa today. Why South Africa Matters, $130(1), 45-70$.

Oneal, J.R., Russett, B. and Berbaum, M.L. 2003. Causes of peace: democracy, independence, and international organizations. International Studies Quarterly, 47, 371-393.

O'Neill, J., Wilson, D., Purushothaman, R. and Stupnytska, A. 2005. How solid are the BRICs? Goldman Sachs Global Economics paper 
No. 134. https://portal.gs.com (Accessed: 12 June 2013).

Simon, D. 1995. Debt, democracy and development: sub-Saharan Africa in the 1990s. In Simon, D., Van Spengen, W., Dixon, C. and Narman, A. (eds.), Structurally Adjusted Africa: Poverty, Debt and Basic Needs. Pluto Press, London.

Statistics South Africa (STATSSA), 2012. South African Statistics 2012. STATSSA, Pretoria.

Tandon, S. and Shome, S. 2009. The cracks in the BRICS. Annals of the University of Petroşani, Economics, 9(4), $273-282$.

Tammen, R.L. 2006. The impact of Asia on world politics: China and India options for the United States. International Studies Review, 6 , 563-580.

Walter, C.E. and Howe, F.J.T. 2011. Red Capitalism: the Fragile Financial Foundation of China's extraordinary Rise. John Wiley \& Son, New York.

Wilson, D., Kelston, A.L. and Ahmed, S. 2010. Is this the "BRICs decade?" BRICs Monthly, 10(3), 1-4.

Wilson, D. and Purushothaman, R. 2003. Dreaming with BRICs: the path to 2050. Global Economics Paper No. 99, October 01, 2003, Goldman Sachs. 